\title{
Development of an RT-LAMP assay for the detection of Lassa viruses in southeast and south-central Nigeria
}

\author{
Christelle M. Pemba ${ }^{\mathrm{a}, \mathrm{b}}$, Yohei Kurosaki ${ }^{\mathrm{a}}$, Rokusuke Yoshikawa ${ }^{\mathrm{a}, \mathrm{c}}$, Olamide K. Oloniniyi ${ }^{\mathrm{a}, \mathrm{b}}$, \\ Shuzo Urata ${ }^{\mathrm{a}, \mathrm{c}}$, Maki Sueyoshi ${ }^{\mathrm{a}}$, Vahid R. Zadeh ${ }^{\mathrm{a}, \mathrm{b}}$, Ifeanyi Nwafor ${ }^{\mathrm{d}}$, Michael O. Iroezindu ${ }^{\mathrm{e}}$, \\ Nnenna A. Ajayi ${ }^{\mathrm{f}}$, Chinedu M. Chukwubike ${ }^{g}$, Nneka M. Chika-Igwenyi ${ }^{\mathrm{f}}$, Anne C. Ndu ${ }^{\mathrm{h}}$, \\ Damian U. Nwidi ${ }^{\mathrm{d}}$, Yuki Maehira ${ }^{\mathrm{a}, \mathrm{i}}$, Uche S. Unigwe ${ }^{\mathrm{d}, \mathrm{j}}$, Chiedozie K. Ojide ${ }^{\mathrm{d}}$, Emeka O. Onwe ${ }^{\mathrm{j}, \mathrm{k}}$, \\ Jiro Yasuda ${ }^{a, b, c, *}$
}

\footnotetext{
${ }^{a}$ Department of Emerging Infectious Diseases, Institute of Tropical Medicine (NEKKEN), Nagasaki University, 1-12-4 Sakamoto, Nagasaki, 852-8523, Japan

${ }^{\mathrm{b}}$ Graduate School of Biomedical Sciences and Program for Nurturing Global Leaders in Tropical and Emerging Communicable Diseases, Nagasaki University, 1-12-4

Sakamoto, Nagasaki, 852-8523, Japan

${ }^{\mathrm{c}}$ National Research Center for the Control and Prevention of Infectious Diseases (CCPID), Nagasaki University, 1-12-4 Sakamoto, Nagasaki, 852-8523, Japan

${ }^{\mathrm{d}}$ Department of Medical Microbiology, Federal Teaching Hospital Abakaliki, P.M.B. 102, Abakaliki, Nigeria

${ }^{\mathrm{e}}$ Department of Medicine, College of Medicine, University of Nigeria, Ituku-Ozalla, P.M.B. 01129, Enugu, Nigeria

${ }^{\mathrm{f}}$ Department of Medicine, University of Nigeria Teaching Hospital, Ituku-Ozalla, P.M.B. 01129, Enugu, Nigeria

${ }^{\mathrm{g}}$ Department of Microbiology, University of Nigeria Teaching Hospital, Ituku-Ozalla, P.M.B. 01129, Enugu, Nigeria

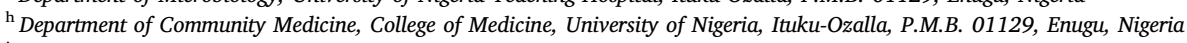

i St Luke's International University, Graduate School of Public Health, 3-6-2, Tsukiji, Chuo-ku, Tokyo, 104-0045, Japan

${ }^{j}$ Department of Medicine, Federal Teaching Hospital Abakaliki, P.M.B. 102, Abakaliki, Nigeria

${ }^{\mathrm{k}}$ Pediatrics Department, Federal Teaching Hospital Abakaliki, P.M.B. 102, Abakaliki, Nigeria
}

A R T I C L E I N F O

\section{Keywords:}

RT-LAMP

Lassa virus

Nigeria

Molecular diagnosis

\begin{abstract}
A B S T R A C T
Lassa virus (LASV) causes Lassa fever (LF), a viral hemorrhagic fever endemic in West Africa. LASV strains are clustered into six lineages according to their geographic location. To confirm a diagnosis of LF, a laboratory test is required. Here, a reverse transcription loop-mediated isothermal amplification (RT-LAMP) assay using a portable device for the detection of LASV in southeast and south-central Nigeria using three primer sets specific for strains clustered in lineage II was developed. The assay detected in vitro transcribed LASV RNAs within $23 \mathrm{~min}$ and was further evaluated for detection in 73 plasma collected from suspected LF patients admitted into two health settings in southern Nigeria. The clinical evaluation using the conventional RT-PCR as the reference test revealed a sensitivity of $50 \%$ in general with $100 \%$ for samples with a viral titer of 9500 genome equivalent copies (geq)/mL and higher. The detection limit was estimated to be $4214 \mathrm{geq} / \mathrm{mL}$. The assay showed $98 \%$ specificity with no cross-reactivity to other viruses which cause similar symptoms. These results suggest that this RT-LAMP assay is a useful molecular diagnostic test for LF during the acute phase, contributing to early patient management, while using a convenient device for field deployment and in resource-poor settings.
\end{abstract}

\section{Introduction}

Lassa fever (LF) is a viral hemorrhagic fever (VHF) responsible for an acute and often fatal illness. LF is endemic in Western African countries such as Nigeria, Sierra Leone, Guinea, and Liberia and eventually affected Mali and Ivory Coast (Branco et al., 2011; FichetCalvet and Rogers, 2009; Manning et al., 2015). Approximately 100,000 to 300,000 clinical infections and 5000 deaths per year are estimated in those regions (Hallam et al., 2018). In 2018, Nigeria experienced the largest LF outbreak with 548 laboratory-confirmed cases reported by October 28th. This epidemic was associated with a fatality rate of $25.7 \%$, where $82 \%$ of confirmed cases were identified in the southern part of the country (Nigeria Centre for Disease Control, 2018). Lassa virus (LASV) that causes the disease belongs to the order $\mathrm{Bu}$ nyavirales family Arenaviridae genus Mammarenavirus. LASV genome consists of two single-stranded RNA segments, L (7.3 kb) and S (3.4 kb),

\footnotetext{
* Corresponding author at: Department of Emerging Infectious Diseases, Institute of Tropical Medicine (NEKKEN), Nagasaki University, 1-12-4 Sakamoto, Nagasaki, 852-8523, Japan.

E-mail address: j-yasuda@nagasaki-u.ac.jp (J. Yasuda).
} 
encoding two proteins each, Z (matrix protein) and L (RNA-dependent RNA polymerase), and NP (nucleoprotein) and GPC (glycoprotein complex), respectively (Andersen et al., 2015). LASV is mainly transmitted to humans through contamination of households and food by excreta from the rodent Mastomys natalensis, which is the natural reservoir of the virus. Recently evidence of LASV hosted by two other rodent species was found, including Hylomyscus pamfi in Nigeria and Mastomys erytroleucus in Nigeria and Guinee (Olayemi et al., 2016). However, human-to-human transmission has occasionally occurred in hospital settings (Gabriel et al., 2018).

LASV strains are genetically diverse and clustered into six main lineages according to their geographic location. Lineages I, II, and III are prevalent in Nigeria, while lineage IV circulates in Guinea, Sierra Leone, and Liberia. Even inside Nigeria, the lineage distribution is related to the geographic location. Lineage I strains are from the northeastern region, lineage II are from the south-central region and southeast, and lineage III can be found in north-central Nigeria (Andersen et al., 2015; Bowen et al., 2000; Ehichioya et al., 2011; Whitmer et al., 2018). Recently two more lineages were suggested, including lineage $V$, consisting of LASV strains isolated in Mali, Cote d'Ivoire, and Ghana, and lineage VI consisting of a strain isolated from a cluster of human infections epidemiologically linked to Togo (Safronetz et al., 2010; Whitmer et al., 2018).

The clinical recognition of LF represents a challenge due to the symptom similarities with other febrile illnesses prevalent in the LASV affected areas such as other VHFs, malaria, shigellosis, and typhoid fever (Dahmane et al., 2014; Hamblion et al., 2018). Ribavirin, the antiviral drug used against LF, is effective only when given in the early stage of the disease, preferably within the first six days after onset (16). Reliable laboratory diagnostics are key for the confirmation of LF, patient management, as well as response to an outbreak. Presently, LASV diagnostics are based on the detection of viral antigens, nucleic acids, and IgM antibodies. To identify LASV, enzyme-linked immunosorbent assay (ELISA), reverse transcription polymerase chain reaction (RTPCR), and tissue culture methods have been developed (Drosten et al., 2003; Hallam et al., 2018; Hamblion et al., 2018). However, owing to their high sensitivity and specificity, conventional and real-time RTPCR are the chosen reference methods for the diagnosis of LF (Raabe and Koehler, 2017).

Reverse transcription loop-mediated isothermal amplification (RTLAMP) is an RNA detection method that combines rapidity, simplicity, and high specificity. The method performs cDNA synthesis and DNA amplification at a constant temperature using four to six specific oligonucleotide primers with a particular reverse transcriptase and a DNA polymerase possessing strand displacement activity (Nagamine et al., 2002, 2001; Notomi, 2000). LAMP reactions can be carried out using simple techniques and equipment, offering a cost-effective diagnosis of infectious diseases. Therefore, it is suitable to be used in resources poor settings and deployed in the field to improve patients' management (Kurosaki et al., 2017; Mori and Notomi, 2009; Oloniniyi et al., 2017; Wong et al., 2018). Efficient multiplex LAMP assays for the simultaneous detection of diverse sequences have also been reported (Iseki et al., 2007; Kurosaki et al., 2017, 2010).

In this study, a rapid and easy-to-perform RT-LAMP assay was developed for the detection of LASV in southeast and south-central Nigeria using a portable battery-powered device, which can be applied for field deployment and thus, contributes to early disease management and medical team response during outbreaks. Further, the assay's clinical use for laboratory diagnosis was evaluated using samples collected from suspected LF patients admitted to the Federal Teaching Hospital Abakaliki (FETHA) and the University of Nigeria Teaching Hospital (UNTH), Enugu.

\section{Materials and methods}

\subsection{Cells and viral RNAs}

Vero 76 cells were obtained from the Health Science Research Resources Bank (JCRB9007) and were maintained in Dulbecco's modified Eagle's medium (DMEM) supplemented with 1\% penicillin/ streptomycin and $10 \%$ fetal bovine serum (FBS). Junin virus (Argentinian mamarenavirus) Candid\#1 was received from Dr. J.C. de la Torre (The Scripps Research Institute, La Jolla, CA, USA). The Armstrong strain of recombinant lymphocytic choriomeningitis virus (LCMV) was rescued using the reverse genetics method and propagated in Vero 76 cells. All viral stocks were stored at $-80^{\circ} \mathrm{C}$ (Flatz et al., 2006). Viral RNAs from filoviruses, Lassa virus Pinneo and Josiah strains, and arboviruses, as well as genomic DNA from Plasmodium falciparum strain 3D7, were obtained as previously described (Kurosaki et al., 2017; Oloniniyi et al., 2017).

\subsection{Preparation of standard RNAs}

Standard RNAs were synthesized for six representative LASV isolates from lineage II. The RNAs consisted of partial GPC genome sequences of LASV isolates, including Nig08-04, Nig16-02, Nig08-A37, ISTH 0012-NIG-2011, ISTH 2065-NIG-2012, and 803,213 (GenBank accession numbers GU481068, LC387482, GU481074, KM821914, KM821974, and AF181854, respectively). The full GPC coding sequence of Nig16-02, an isolate from Abakaliki in Ebonyi State in 2016 (Oloniniyi et al., 2018), was amplified by RT-PCR using forward (5'ATGGGACAAATAGTAACATTCTTTCAGG- $3^{\prime}$ ) and reverse (5'-CTATCTC TTCCACTTGACTGGTACACCAGG $-3^{\prime}$ ) primers using the QIAGEN OneStep RT-PCR Kit (Hilden, Germany). The reactions were performed using the Takara PCR Thermal Cycler Dice with the following program: $50{ }^{\circ} \mathrm{C}$ for $30 \mathrm{~min}, 95^{\circ} \mathrm{C}$ for $15 \mathrm{~min}$, followed by 40 cycles of $94^{\circ} \mathrm{C}$ for $30 \mathrm{~s}, 55^{\circ} \mathrm{C}$ for $30 \mathrm{~s}$, and $72{ }^{\circ} \mathrm{C}$ for $90 \mathrm{~s}$, followed by $72{ }^{\circ} \mathrm{C}$ for $7 \mathrm{~min}$ and a $4{ }^{\circ} \mathrm{C}$ hold. The other $481 \mathrm{bp}$ DNA fragments were synthesized by IDT (Integrated DNA technologies, Coralville, IA, USA), with the addition of a 5' A-overhang to facilitate TA cloning using the Mighty TA-cloning Reagent set for PrimeSTAR (Takara Bio, Shiga, Japan). All DNA fragments were cloned into the PCR2.1 vector using the TOPO TA Cloning Kit (Invitrogen, Carlsbad, CA, USA). The plasmids were digested with BamHI and purified from an agarose gel using a column purification kit (QIAGEN) and subsequently used as templates for RNA expression. The partial genomic RNAs of each LASV isolate were synthesized in vitro from the templates using T7 RNA polymerase (Promega, Madison, WI, USA) and purified using the RNeasy Mini Kit (QIAGEN). The RNA concentration was determined by measuring the optical density at $260 \mathrm{~nm}$ with a NanoDrop 2000 (ThermoFisher Scientific, Waltham, MA, USA), and the RNAs were diluted in DEPC-treated water to achieve the desired concentrations.

\subsection{Primer design}

LAMP primers for LASV lineage II detection were designed based on the coding sequences from GPC. The nucleotide sequences of LASV lineage II isolates, which are available in the GenBank database, were aligned using sequence analysis software (GENETYX, Tokyo, Japan) to identify conserved regions. A consensus sequence for a region in the selected gene was used to design LAMP primers using LAMP Designer software (Optigene, http://www.optigene.co.uk/lamp-designer/). Three subclade-specific primer sets were designed. Primers specific for Ebonyi isolates were designed first, followed by an Anambra isolatespecific primer set, which was designed by adapting each position to the Ebonyi isolates consensus sequence. Finally, an Edo isolate-specific primer set was designed in a different position. The location of each state in Nigeria was shown in Fig. 1. The RT-LAMP assay requires a set of six primers, including two outer primers (F3 and B3), a forward inner 


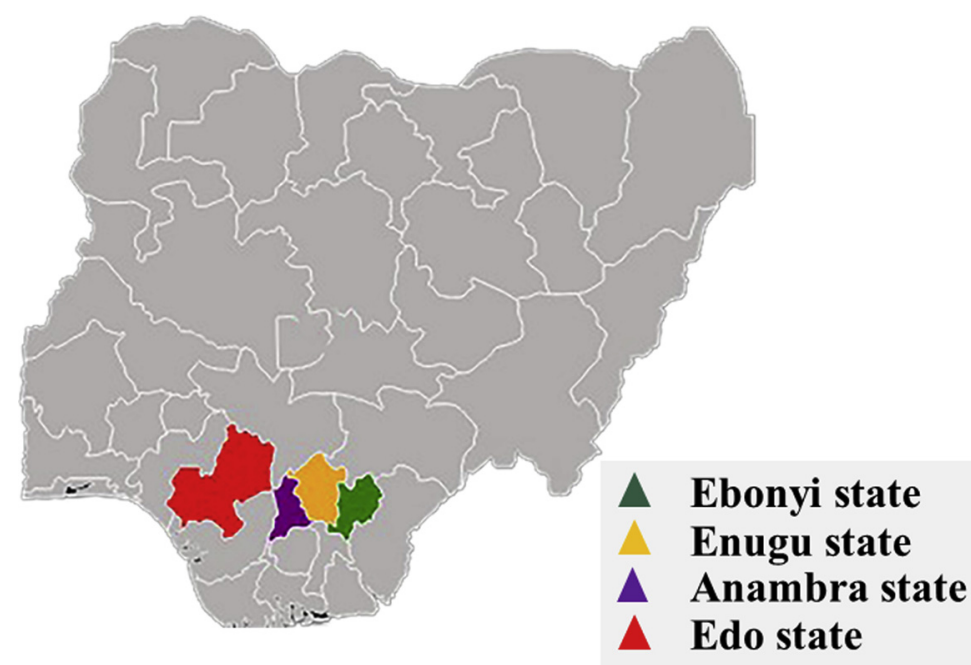

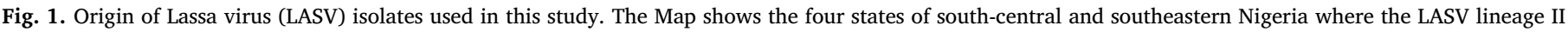
strains have been isolated so far.

Table 1

Sequence of loop-mediated isothermal amplification (LAMP) primers.

\begin{tabular}{|c|c|c|c|}
\hline Name & Type & ${ }^{\mathrm{a}}$ Position & 'bequence(5'-3') \\
\hline \multirow[t]{8}{*}{ Lv-II-Se } & F3 & $780-799$ & TGCTGTCACAGAGAACTAGA \\
\hline & B3 & $1032-1050$ & ATGCTCATCTGTGCTTCTG \\
\hline & F1c & $866-885$ & CAGTATCCACCGGGTGCTTC- \\
\hline & $\mathrm{F} 2$ & $814-832$ & TCGGAGACTTCTTGGAACT \\
\hline & B1c & $911-932$ & GCTGAATTGAAGTGCTTTGGGA- \\
\hline & B2 & $962-983$ & TATCACAGAATTCCTCATCGTG \\
\hline & $\mathrm{LF}$ & $846-864$ & TTGCCCTCAGAGTCAGAGA \\
\hline & LB & $934-954$ & CACAGCCATTGCAAAGTGTAA \\
\hline \multirow[t]{8}{*}{ Lv-II-Sc1 } & F3 & $780-799$ & TATTGTCACAGAGAACTAGA \\
\hline & B3 & $1032-1050$ & ATACTCATCTGTGCㅡCTG \\
\hline & F1c & $866-885$ & CAGTACCCACCAGGTGTTCT- \\
\hline & $\mathrm{F} 2$ & $814-832$ & TCGAAGACTTCTEGGAACE \\
\hline & B1c & $911-932$ & GCAGGAACTGAAGTGCTTTGGGA- \\
\hline & B2 & $962-983$ & TGTCACA-AAATTCTTCATCATTG \\
\hline & LF & $846-864$ & TTGCCITCAGA $\underline{A T C A G A} \underline{A}$ \\
\hline & LB & $934-954$ & CACAGCAGTCGCAAAGTGㅡAA \\
\hline \multirow[t]{8}{*}{ Lv-II-Sc2 } & F3 & $791-809$ & AGGACCAGGGACATTTACA \\
\hline & B3 & $1016-1035$ & TCTGTCTTCAGCCTCCTTAT \\
\hline & F1c & $865-885$ & CAATACCCACCCGGTGTTTCA \\
\hline & $\mathrm{F} 2$ & $815-834$ & CGAAGACTTCTTGGGACTTT \\
\hline & $\mathrm{B} 1 \mathrm{c}$ & $898-918$ & GATGCTGATTGAGGCCGAGTT \\
\hline & B2 & $944-963$ & TGTTTCTCATTGCATTTCGC \\
\hline & $\mathrm{LF}$ & $840-861$ & TCAGAATCAGAGAGAGTCCAAGT \\
\hline & LB & $919-938$ & AAGTGCTTTGGGAACACAGC \\
\hline
\end{tabular}

a Primer position in the Lassa virus isolate Nig08-04 (Genbank accession number: GU481068).

$\mathrm{b}$ Underlines indicate the positions of nucleotides adapted to Anambra and some Edo isolates.

primer (FIP), a reverse inner primer (BIP), a forward loop primer (LF), and a reverse loop primer (LB). The FIP consisted of the F1c sequence, which is complementary to the F1 and F2 sequences. The BIP consisted of the B1c sequence, which is complementary to the B1 and B2 sequences. The sequences and locations of the oligonucleotide primers are shown in Table 1 and Fig. 2.

\subsection{RT-LAMP assay}

RT-LAMP was performed with an Isothermal Master Mix reagent (OptiGene, West Sussex, UK) using the Genelyzer FIII real-time fluorescence detection platform (Canon Medical Systems, Otawara, Japan). The reaction mixture (total volume, $25 \mu \mathrm{L}$ ) contained $15 \mu \mathrm{L}$ of Isothermal Master Mix, $1 \mu \mathrm{L}$ of avian myeloblastosis virus reverse transcriptase ( $0.15 \mathrm{U}$; Life Technologies, Carlsbad, CA, USA), $3 \mu \mathrm{L}$ of the LAMP primer mix consisting of 5 pmol F3 and B3, 20 pmol FIP and BIP, $10 \mathrm{pmol} \mathrm{LF}$ and LB, $4 \mu \mathrm{L}$ of DEPC-treated distilled water, and $2 \mu \mathrm{L}$ of RNA sample as the template. The assay was carried out using a mixture of primers specific for the Ebonyi, Edo, and Anambra LASV isolates. All primers were cartridge-purified oligonucleotides purchased from Hokkaido System Science (Sapporo, Japan). The reaction was performed at $63{ }^{\circ} \mathrm{C}$ for $30 \mathrm{~min}$. DEPC-treated distilled water or an in vitro transcribed RNA from Nig16-02 was used as a negative or positive control, respectively.

\subsection{Conventional RT-PCR}

Conventional RT-PCR was performed with the LASV-specific primers described previously, 36E2 (5'-ACCGGGGATCCTAGGCATTT-3') and LVS-339-rev (5'- GTTCTTTGTGCAGGAMAGGGGCATKGTCAT-3') (Olschlager et al., 2010). Amplification was carried out in a total reaction volume of $25 \mu \mathrm{L}$ using a OneStep RT-PCR Kit (QIAGEN) with $10 \mu \mathrm{M}$ forward and reverse primers and $2 \mu \mathrm{L}$ of RNA sample. The thermal conditions were $50^{\circ} \mathrm{C}$ for $30 \mathrm{~min}$ and $95^{\circ} \mathrm{C}$ for $15 \mathrm{~min}$, followed by 45 cycles of $95^{\circ} \mathrm{C}$ for $30 \mathrm{~s}, 52^{\circ} \mathrm{C}$ for $30 \mathrm{~s}$, and $72{ }^{\circ} \mathrm{C}$ for $30 \mathrm{~s}$, and $72{ }^{\circ} \mathrm{C}$ for $7 \mathrm{~min}$, and a $4{ }^{\circ} \mathrm{C}$ hold. LCMV RNA amplification was carried out in a total reaction of $25 \mu \mathrm{L}$ using PrimeScript OneStep RT-PCR Kit Ver. 2 (Takara Bio) with $10 \mu \mathrm{M}$ forward (5'-CAGGAATTCCCATGGGTCAAGG CAAGTCC-3') and reverse (5'-CGGGAATTCTTACTCTTCGTAGGGAGG TGG-3') primers and $0.5 \mu \mathrm{L}$ of RNA sample with the following conditions $50{ }^{\circ} \mathrm{C}$ for $30 \mathrm{~min}, 94^{\circ} \mathrm{C}$ for $2 \mathrm{~min}$, followed by 40 cycles of $94^{\circ} \mathrm{C}$ for $30 \mathrm{~s}, 50{ }^{\circ} \mathrm{C}$ for $30 \mathrm{~s}$ and $72{ }^{\circ} \mathrm{C}$ for $30 \mathrm{~s}$, and a $4{ }^{\circ} \mathrm{C}$ hold. Finally, RNAs of filoviruses were amplified using primers targeting the viral nucleoprotein (NP) gene at the thermal conditions previously described (Ogawa et al., 2011). The reactions were performed using the Takara PCR Thermal Cycler Dice (Takara Bio).

\subsection{Quantitative real-time RT-PCR}

Copy numbers of LASV RNA in PCR and/or LAMP-positive samples were quantified by quantitative real-time RT-PCR (qRT-PCR) using forward (5'-TRTGTGGAAGATCATGCTCAACAACC- 3 ') and reverse (5'-GTTRAGGTTTGCCATRTCCARCTC-3') primers specific for Abakaliki isolates (from Ebonyi state). The in vitro transcribed RNA from isolate Nig16-02 was used as a standard. Junin virus RNA was amplified using specific forward (5'-CCAACCTTTTTGCAGGAGGC-3') and reverse (5'TTCCTGCAAGCGCTAGGAAT-3') primers. One-Step TB Green PrimeScript PLUS RT-PCR Kit (Takara Bio) was used under the 


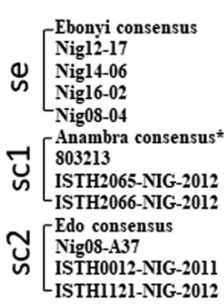

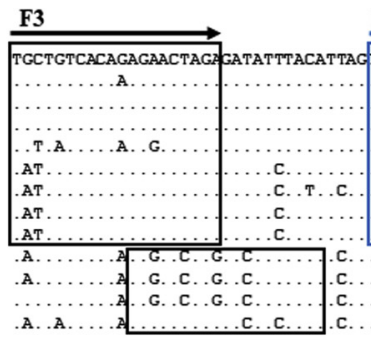

F2
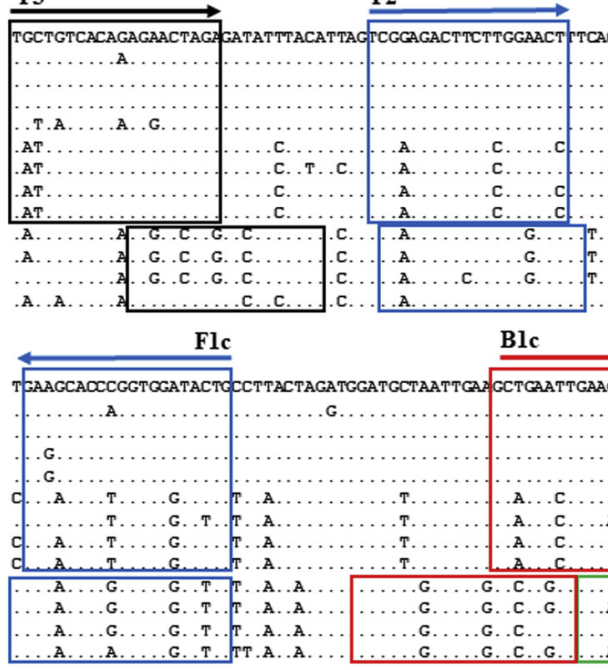

Blc

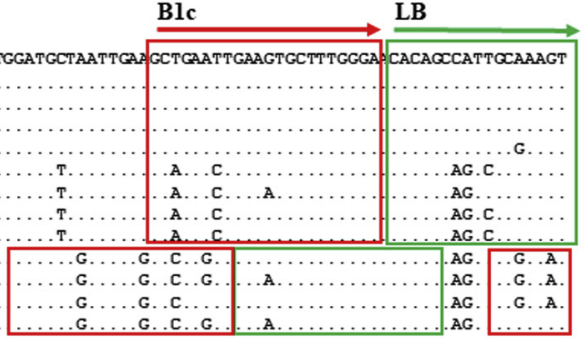

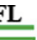
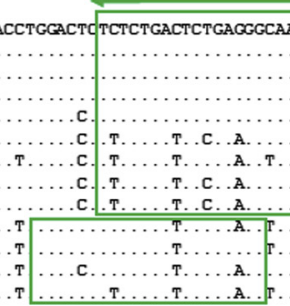

……

T......c.

a.c.c

T. T. T C A

C. T. . . T. C. A T.C.A. T....A. $\mathrm{T}$.

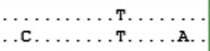

Ebonyi consensus
Nig12-17
Nig14-06
Nig16-02
Nig08-04
Anambra consensus
803213
ISTH2065-NIG-2012
ISTH2066-NIG-2012
Edo consensus
Nig08-A37
ISTH0012-NGG-2011
ISTH1121-NIG-2012

Ebonyi consensus

Nigl2-17

Nigl4-06

Nigl6-02

Nig08-04

Anambra consensus

803213

ISTH2065-NIG-2012

ISTH2066-NIG-2012

Edo consensus

Nig08-A37

ISTH0012-NGG-2011

ISTH1121-NIG-2012

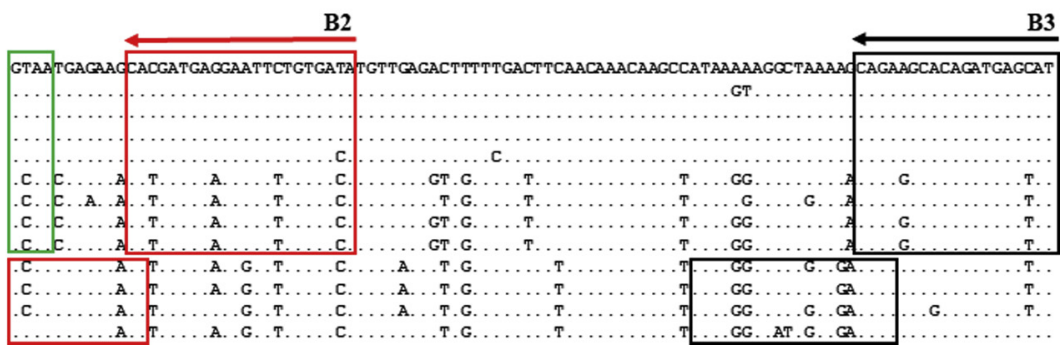

Fig. 2. Specificity of the loop-mediated isothermal amplification (LAMP) primers for Lassa virus (LASV) sequences. Alignment of LASV sequences and positions of LAMP primers are shown. Boxes are the sites recognized by each oligonucleotide primer and arrows show the direction of each primer. LvII-Se and Lv-II-Sc1 primers share the same position whereas Lv-II-Sc2 primers are in a different position than the others. The Genbank accession numbers for the strains are LC387468, LC387476, LC387482, GU481068, AF181854, KM821974, KM821976, GU481074, KM821914, and KM821945 (from top to bottom). following thermal conditions: $42^{\circ} \mathrm{C}$ for $5 \mathrm{~min}, 95^{\circ} \mathrm{C}$ for $10 \mathrm{~s}$ and 40 cycles of $95^{\circ} \mathrm{C}$ for $5 \mathrm{~s}$ and $60^{\circ} \mathrm{C}$ for $30 \mathrm{~s}, 95^{\circ} \mathrm{C}$ for $15 \mathrm{~s}, 60^{\circ} \mathrm{C}$ for $1 \mathrm{~min}$ and $95{ }^{\circ} \mathrm{C}$ for $15 \mathrm{~s}$. The reactions were performed using the StepOnePlus Real-Time PCR System (Applied Biosystems, ThermoFisher Scientific).

\subsection{Clinical samples}

A total of 73 blood samples were collected from patients with suspected acute LF at the FETHA and UNTH from 2012 to 2016 into EDTA tubes. Plasma samples were inactivated using TRIzol LS Reagent (ThermoFisher) followed by phase separation using $200 \mu \mathrm{L}$ of chloroform. Viral RNAs were then extracted from the inactivated plasma using a QIAmp Viral RNA Mini Kit according to the manufacturer's instructions (QIAGEN) and shipped to Nagasaki University following the approved protocol.

\subsection{Ethical statements}

This study was approved by the Institutional Ethical Committee of Nagasaki University (approval number 140829131) and the Ethical Committee on Research of the Enugu State Ministry of Health (approval number $\mathrm{MH} / \mathrm{MSD} / \mathrm{EC} / 0129)$. Informed consent was obtained and samples were collected from adult patients as part of the response to contain the outbreak. Work was conducted in accordance with the protocols of the FETHA and UNTH.

\section{Results}

\subsection{Sensitivity of the assay}

LASV lineage II strains which have been isolated thus far are genetically divided into 2 subclades, Se (isolates from southeastern Nigeria, Ebonyi and Enugu States) and Sc (isolates from south-central Nigeria, Anambra and Edo States). Sc strains are further divided into 2 subgroups, Sc1 (isolates from Anambra and Edo States) and Sc2 (isolates from Edo State) (Figs. 1 and 2). RT-LAMP primer sets specific for each subclade/subgroup were designed, targeting conserved sequences that encode the extracellular domain of the viral surface glycoprotein, GPC, for the detection of all known LASV isolates clustered in lineage II. Lv-II-Se and Lv-II-Sc1 primer sets were expected to detect the isolates in the southeastern states, as well as the isolates in Anambra state and minor parts of the lineage II isolates in Edo state, respectively. These primer sets recognize the same genomic position while the Lv-IISc2 set, which detects a major part of the lineage II isolates in Edo state, recognizes a different, but overlapping genomic position than the other two sets of primers (Table 1 and Fig. 2). To detect all known LASV isolates belonging to the lineage II, a mixture of these three specific primer-sets was used in a single reaction. The sensitivity of the assay was examined using serial 10-fold dilution of in vitro transcribed RNAs from six representative isolates of LASV lineage II in which included, two Se isolates, Nig16-02 and Nig08-04, one Sc1 isolate, 803213, and three Sc2 isolates, Nig08-037, ISTH0012-NIG-2011, and ISTH2065NIG-2012. Both older and recent isolates for each subclade were chosen, with the exception of the third strain (ISTH2065-NIG-2012) of the Sc2 subclade, which was selected due to its low sequence identity to the other isolates from the same State. All of the representative isolates were from human specimens. Two independent experiments using duplicate samples detected up to $2 \times 10^{3}$ copies of RNAs per reaction for ISTH0012-NIG-2011, ISTH2065-NIG-2012, and 803213 strains. The assay could detect $2 \times 10^{2}$ copies for Nig08-04 and Nig08-037 strains and 20 copies for the Nig16-02 strain (Table 2). The detection times for positive results for synthesized RNAs ranging from $2 \times 10^{1}$ to $2 \times 10^{6}$ copies were mostly less than $23 \mathrm{~min}$. These results suggested that the RT-LAMP assay could be used as a rapid diagnostic test, which is sufficiently sensitive for the detection of LASV lineage II.

\subsection{Specificity of the assay}

To evaluate the specificity of the RT-LAMP assay for LASV lineage II strains, the assay's cross-reactivity for other lineages of LASV was 
Table 2

Detection limits of Lassa virus lineage II isolates by the reverse transcription loop-mediated isothermal amplification (RT-LAMP) assay.

\begin{tabular}{|c|c|c|c|c|c|c|}
\hline \multirow[t]{3}{*}{ Copies per rxn } & \multicolumn{2}{|c|}{ Detection time $(\min )^{\mathrm{a}}$} & \multirow{3}{*}{$\begin{array}{l}\text { Anambra } \\
803213\end{array}$} & \multirow{2}{*}{\multicolumn{2}{|c|}{ Edo }} & \multirow[b]{3}{*}{ ISTH2065-NIG-2012 } \\
\hline & \multicolumn{2}{|l|}{ Ebonyi } & & & & \\
\hline & Nig08-04 & Nig16-02 & & Nig08-A37 & ISTH0012-NIG-2011 & \\
\hline $2 \times 10^{6}$ & $9.1 \pm 0.8$ & $8.6 \pm 0.9$ & $14.9 \pm 1.7$ & $9.6 \pm 2.2$ & $9.8 \pm 1.5$ & $13.3 \pm 1.1$ \\
\hline $2 \times 10^{5}$ & $10.5 \pm 1.7$ & $10.7 \pm 0.2$ & $16.7 \pm 2.8$ & $10.6 \pm 3.1$ & $11.1 \pm 2.0$ & $15.7 \pm 0.3$ \\
\hline $2 \times 10^{4}$ & $11.9 \pm 1.9$ & $12.1 \pm 0.4$ & $18.3 \pm 3.2$ & $12.3 \pm 3.9$ & $13.1 \pm 3.6$ & $17.7 \pm 0.6$ \\
\hline $2 \times 10^{3}$ & $15.0 \pm 3.4$ & $13.7 \pm 0.4$ & $23.0 \pm 6.6$ & $16.0 \pm 4.8$ & $15.0 \pm 3.1$ & $21.4 \pm 2.1$ \\
\hline $2 \times 10^{2}$ & $15.1 \pm 4.4$ & $14.7 \pm 1.0$ & - & $20.6 \pm 2.2$ & - & - \\
\hline $2 \times 10^{1}$ & - & $16.4 \pm 4.1$ & - & - & - & - \\
\hline
\end{tabular}

- : Not detected.

a Data represents mean \pm standard deviation of two independent experiments.

Table 3

Species specificity of Lassa virus lineage II reverse transcription loop-mediated isothermal amplification (RT-LAMP).

\begin{tabular}{|c|c|c|c|c|}
\hline Family & Genus & Species & Strain & Results of RT-LAMP \\
\hline \multirow[t]{4}{*}{ Arenaviridae } & \multirow[t]{4}{*}{ Mammarenavirus } & Lassa mamarenavirus & Pinneo & - \\
\hline & & Lassa mamarenavirus & Josiah & - \\
\hline & & Lymphocytic choriomeningitidis mammarenavirus & Armstrong & - \\
\hline & & Argentinian mamarenavirus & Candid \#1 & - \\
\hline \multirow[t]{5}{*}{ Filoviridae } & \multirow[t]{3}{*}{ Ebolavirus } & Sudan ebolavirus & Boniface & - \\
\hline & & Tai Forest ebolavirus & Pauléoula & - \\
\hline & & Zaire ebolavirus & Kikwit & - \\
\hline & \multirow[t]{2}{*}{ Marburgvirus } & Marburg Marburgvirus & Musoke & - \\
\hline & & Marburg Marburgvirus & Ravn & - \\
\hline \multirow[t]{8}{*}{ Flaviviridae } & \multirow[t]{8}{*}{ Flavivirus } & Zika virus & 976Uganda & - \\
\hline & & Zika virus & PRABC59 & - \\
\hline & & Dengue virus serotype 1 & Hawaii & - \\
\hline & & Dengue virus serotype 2 & ThNH7/93 & - \\
\hline & & Dengue virus serotype 3 & PhMH-J1-97 & - \\
\hline & & Dengue virus serotype 4 & SLMC 318 & - \\
\hline & & Yellow fever virus & 17D & - \\
\hline & & West Nile virus & NY99 & - \\
\hline Togaviridae & Alphavirus & Chikungunya virus & 10Mdy30 & - \\
\hline Orthomyxoviridae & Influenza virus $A$ & Influenza A virus & A/PR/8/1934(H1N1) & - \\
\hline Phenuiviridae & Phlebovirus & Rift Valley fever phlebovirus & SPU22/07 & - \\
\hline Plasmodiidae & Plasmodium & Plasmodium falciparum & 3D7A & - \\
\hline
\end{tabular}

- : Not detected.

examined. This included other arenaviruses, a variety of viruses belonging to Filoviridae, Flaviviridae, Togaviridae, Orthomyxoviridae, and Phenuiviridae families, as well as Plasmodium falciparum, which may be found in areas where LF outbreaks occur or cause similar febrile illness (Table 3). A total of $10^{6}$ copies of viral RNAs extracted from viruses propagated in cells in vitro and $1 \mathrm{ng}$ of genomic DNA of $P$. falciparum were used for these experiments. The assay showed no cross-reactivity with these pathogens, suggesting that it is highly specific for lineage II LASV strains.

\subsection{Clinical evaluation}

To assess the clinical usage of the RT-LAMP assay for laboratory diagnosis of LF, the assay was evaluated using plasma samples collected from suspected LF patients admitted to FETHA, Ebonyi state, and to UNTH, Enugu state, from 2012 to 2016. A total of 73 suspected LF cases were subjects in this study and RNA was extracted from their plasma samples. Conventional RT-PCR was applied for the same RNA samples as a reference diagnostic test to confirm the LASV infection. Fourteen samples were positive in the conventional RT-PCR test, whereas eight were positive in the RT-LAMP test. Sensitivity, specificity, positive predictive value (PPV), negative predictive value (NPV), and accuracy of the RT-LAMP assay were evaluated. Using the mixture of primers, the RT-LAMP assay showed a specificity of $98 \%$, a sensitivity of $50 \%$, a PPV of $87 \%$, a NPV of $89 \%$, and an accuracy of $89 \%$, all with a $95 \%$ confidence level (Table 4). Seven out of eight positive results in the LAMP
Table 4

Diagnostic accuracy of the reverse transcription loop-mediated isothermal amplification (RT-LAMP) test for Lassa virus compared with the reference RTPCR test.

\begin{tabular}{llll}
\hline \multirow{2}{*}{ RT-LAMP } & \multicolumn{2}{l}{ RT-PCR } & \multirow{2}{*}{ Total } \\
\cline { 2 - 3 } & positive & negative & \\
\hline positive & 7 & 1 & 8 \\
negative & 7 & 58 & 65 \\
Total & 14 & 59 & 73 \\
Diagnostic accuracy (95\% CI) & & & \\
$\quad$ Sensitivity & $50 \%(23-77)$ & & \\
$\quad$ Specificity & $98 \%(91-100)$ & & \\
$\quad$ Positive predictive value & $87 \%(47-100)$ & & \\
$\quad$ Negative predictive value & $89 \%(79-96)$ & & \\
$\quad$ Accuracy & $89 \%(80-95)$ & & \\
\hline
\end{tabular}

assay were consistent with the results of the reference test. However, only one result was positive in RT-LAMP but negative in the reference RT-PCR test (sample ID S18/2012). To confirm this inconsistent result, real-time RT-PCR using in-house primers specific for Abakaliki isolates was also performed on S18/2012. Results revealed that this sample was truly positive for LASV, with a Ct value of 22 (Fig. 3). These data suggested that the newly developed RT-LAMP assay was highly specific for the detection of LASV but less sensitive than the conventional RTPCR. 
$\mathbf{A}$

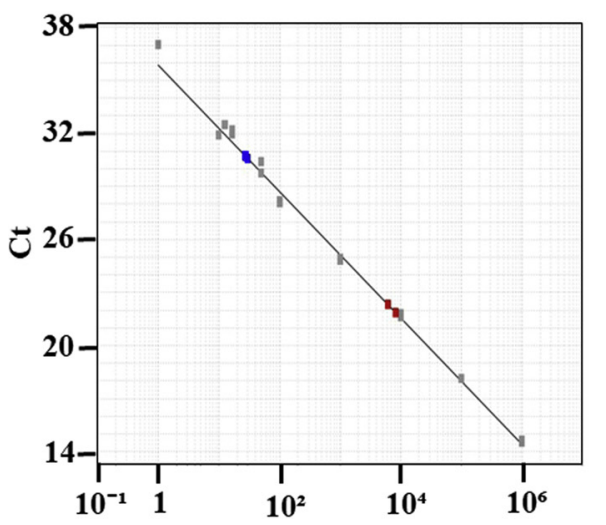

RNA copies/reaction
B

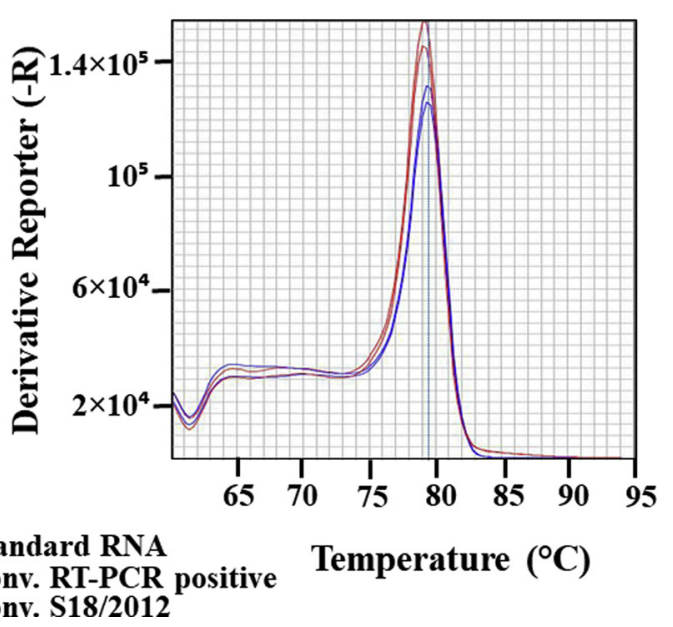

Fig. 3. Detection of the RT-PCR false negative sample $(\mathrm{S} 18 / 2012)$ by quantitative real-time RT-PCR. (A) Duplicates of S18/2012 using a standard curve established by diluting sRNA from the Lassa virus (LASV) Ebonyi strain (Nig16-02), showing a Ct value between 21 and 22. Additionally, the positive control is shown, which is a LASV viral RNA confirmed positive by the conventional RT-PCR assay. (B) S18/2012 melting curve is similar to that of the positive control in an experiment using duplicate samples.
Table 5

Evaluation of the reverse transcription loop-mediated isothermal amplification (RT-LAMP) assay in clinical samples from Nigeria.

\begin{tabular}{|c|c|c|c|c|}
\hline \multirow[t]{2}{*}{$\mathrm{Ct}$} & \multicolumn{2}{|c|}{ RT-LAMP } & \multirow[t]{2}{*}{ Total } & \multirow[t]{2}{*}{$\%$ positive } \\
\hline & Positive & Negative & & \\
\hline$<20$ & 1 & 0 & 1 & 100 \\
\hline $20-25$ & 3 & 0 & 3 & 100 \\
\hline $26-30$ & 1 & 0 & 1 & 100 \\
\hline $31-35$ & 3 & 5 & 8 & 37.5 \\
\hline$\geq 36$ & 0 & 2 & 2 & 0 \\
\hline Total & 8 & 7 & 15 & \\
\hline
\end{tabular}

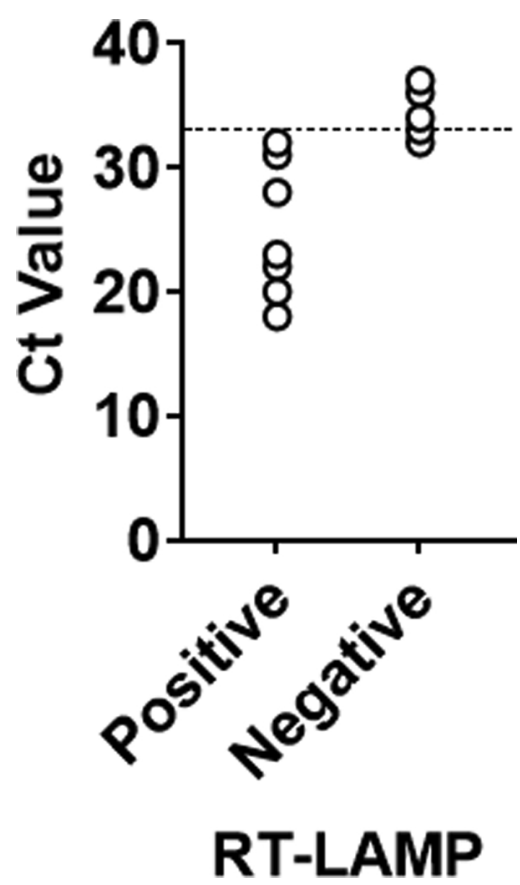

Fig. 4. Characteristics of viral RNA titers in quantitative real-time RT-PCR. The viral titer of fourteen clinical samples that were positive in conventional RTPCR and used for the clinical evaluation of the assay was quantified by real-time RT-PCR using the synthesized RNA from the Lassa virus Ebonyi strain, Nig1602 , as a standard. Samples with a Ct value less than 32 could be detected by the RT- loop-mediated isothermal amplification (LAMP) assay while samples with a Ct value equal to or higher than 32 were negative in the RT-LAMP assay. Data shown are the mean of duplicate samples in one experiment.
To determine the viral load in each sample tested, a quantitative real-time RT-PCR (qRT-PCR) was conducted for the samples that were positive in the reference test or the RT-LAMP test. The samples used for the clinical assessment had a Ct value ranging between 18 and 36, and the viral load of each sample was determined as RNA copies/ml which ranged from 142 to $2.2 \times 10^{7}\left(0.4\right.$ to $6.2 \times 10^{4}$ RNA copies per reaction). The limit of detection was also estimated at 4214 genome equivalent copies (geq)/mL for the samples isolated in Ebonyi and Enugu states, considering the RNA extraction method and input volume of RNA into the reaction. The RT-LAMP positive results were completely consistent with that of the reference RT-PCR test in the samples which showed a Ct value equal to or less than $30(9500 \mathrm{geq} / \mathrm{mL})$ (Table 5). The seven negative results in RT-LAMP showed a Ct value equal or higher than 32 (2303 geq/mL) (Fig. 4).

\section{Discussion}

This group previously reported an RT-LAMP assay for lineage I and IV of LASV (Fukuma et al., 2011). In this study, an RT-LAMP assay for the detection of LASV isolates belonging to lineage II, which is located in the southeastern and south-central regions of Nigeria was developed and evaluated. This Nigerian area was the home of more than $50 \%$ of the confirmed cases during the largest recent outbreak of Lassa fever in 2018 (Nigeria Centre for Disease Control, 2018). The assay was developed in response to the WHO calls for early diagnostic tests for Lassa fever to allow patient treatment at an early disease stage. In addition, there is a need for validated assays based on geographic distribution of LASV and to overcome the lack of adequate results associated with the pan-LASV diagnostic assay (Raabe and Koehler, 2017). The focus on the LAMP method is justified by its features that allow the assay to be an easy and useful tool for rapid diagnostic testing in resource-poor settings and for deployment of prompt management of patients during outbreaks.

Samples from suspected LF patients enrolled in this study came from Ebonyi and Enugu states through the FETHA and UNTH and were previously tested for determining the genetic characterization of lineage II strains in southern Nigeria (Oloniniyi et al., 2018). Therefore, specimens from Anambra and Edo were not available for assay evaluation. The assay's performance as a diagnostic method showed $100 \%$ sensitivity for samples with $\mathrm{Ct}$ values less than or equal to 30 , while the specificity of the assay was determined to be $98 \%$. Furthermore, the possibility of cross-reactivity was tested with a broad range of viruses and $P$. falciparum, which share clinical symptoms with LF and are often reported in LF endemic countries. The assay did not show any crossreaction with these pathogens. It is important to note that there was no 
cross-reactivity to LASV Pinneo and Josiah strains, which belong to lineage I and IV, respectively. Additionally, there was no cross-reactivity to pathogens responsible for VHF, such as Ebola viruses, which caused the largest outbreak of Ebola viral disease in the LASV endemic region in 2014-2016 (Goba et al., 2016). To further evaluate the specificity of the assay, in silico sequence analysis was conducted between LAMP primers and 134 isolates from LASV lineages III, IV, V, and VI (28). The nucleotide identity ranged from 74 to $81 \%$ (data not shown). The testing results, along with the in silico sequence analysis between LAMP primers and lineages III-VI isolates, revealed that the RT-LAMP assay is highly specific for LASV lineage II.

The significant genetic diversity of LASV remains a challenge for developing nucleic acid-based assays, especially in the oligonucleotide design steps, as the presence of even a single nucleotide variant can negatively impact assay sensitivity, depending on the variant location (Raabe and Koehler, 2017). Following the alignment of available viral genome sequences of lineage II strains, LASV strains were regrouped according to the state of their first isolation and divided into 3 subgroups. Then, three subgroup-specific primer sets were designed to cover the detection of all lineage II strains. The mixture of all three subgroup-specific primer sets succeeded in the detection of all of the representative strains, with a sensitivity ranging from 20 to 2000 RNA copies per reaction. This approach successfully worked for the LAMP assays previously developed to detect Babesia parasites and Zika virus with high efficiency (Iseki et al., 2007; Kurosaki et al., 2017). Considering that infected people easily move from one state to another in the same region, it is important to develop an assay able to detect isolates from southeastern and south-central Nigeria.

Today, the RT-PCR is the clinical reference method for the detection of LF with high sensitivity and specificity. The GPC RT-PCR/2007 developed by Olschläger et al. delivers results within $2-3 \mathrm{~h}$ and has a detection limit of 342-2560 geq/mL, depending on the virus strain, and the assay can detect a broad range of LASV strains (Olschlager et al., 2010). However, the assay requires a highly equipped laboratory and considerable skill. Therefore, this method is difficult to implement in rural and remote areas. In contrast, the major advantages of the RTLAMP assay developed in this study are the rapid results, with positive results available within $23 \mathrm{~min}$, and the use of a portable and easy-tohandle equipment, which is a battery-equipped device of $1.7 \mathrm{~kg}$ and can run for about $3 \mathrm{~h}$ without a power source connection. Therefore, it can be carried anywhere as a part of a mobile laboratory. This assay offers the possibility of use in the field or in ill-equipped laboratory settings and an accessible diagnostic test of LF to the most affected population living in rural and remote areas, that may improve the patient management and contribute to a quick outbreak response (Kurosaki et al., 2016). Furthermore, the one false-positive result observed while testing negative samples was later confirmed to be truly positive for LASV by testing with another real-time RT-PCR assay. Potential template-primer mismatches with the conventional RT-PCR primers may explain this result. Also, besides its simplicity and rapidity, the LAMP method is known for its high specificity due to the use of six different primers recognizing eight distinct regions of the target sequence, suggesting a greater level of specificity than the paired primer approach used in PCR assays (Notomi et al., 2015). These results revealed that the RT-LAMP assay can detect some RT-PCR false-negative cases in lineage II isolates. The inhabitants of rural areas, where the rodent-natural reservoir lives, are most at risk to be infected by LASV (World Health Organization, 2018).The developed assay coupled with a portative device is suitable for use as a rapid and simple test of suspected LASV cases in primary care settings and in remote areas during outbreaks.

The RT-LAMP assay showed its ability to detect LASV lineage II in the clinical evaluation. However, the sensitivity of the assay could be a potential limitation for diagnosis, and is probably due to the number of oligonucleotide primers used in the assay. The sensitivity was revealed to be related to the viral RNA titer since the assay was able to detect a viral titer associated with a Ct value of less than 32 (Fig. 4). This value was estimated to be equal to $4214 \mathrm{geq} / \mathrm{mL}$ (11.8 copies per reaction) which is higher than the RT-PCR reference test limit of detection (342-2560 geq $/ \mathrm{mL})$. As the LASV RNA titers were found to be higher at $7 \times 10^{6}$ and $1.6 \times 10^{7} \mathrm{geq} / \mathrm{mL}$ in serum of patients with LF at days four and seven post onset of clinical symptoms, respectively (Branco et al., 2011; Drosten et al., 2002), the developed assay seemed to be able to detect viral RNA in the clinical samples during the acute phase of infection. Because of the limited access to the clinical records, "the day after onset" of each collected sample could not be identified. To further evaluate the assay's usage as a LF diagnostic test, increasing the sample size and considering serum viremia over time during human disease would be needed.

In this study, the mixture of the primer sets for three subclades were developed, while the single assays using the primer set for each subclade were also examined. They showed higher sensitivities than that using the mixing primer sets (data not shown). Therefore, it would be available when only a few samples are tested, although three reactions for a sample are required. Alternatively, to increase the accuracy of the diagnostic assay, it may be considered to use RT-PCR assay as a second test.

The viral diversity represents another potential limitation of the assay as observed for the GPC RT-PCR/1994 assay, which required an improvement after the occurrence of false-negative results (Demby, 1994; Olschlager et al., 2010). The RT-LAMP assay considered the sequences available in Genbank by May 2017 and sequences provided by this research group (Oloniniyi et al., 2018). However, recently, many new LASV lineage II sequences were released. The LASV sequences isolated in the FETHA and UNTH belonged to the same sublineage of the lineage II. However, the possibility of finding positive cases from other lineages inside the lineage II territory cannot be excluded. Therefore, lineage III should be considered in laboratory diagnosis, especially for the interpretation of the RT-LAMP negative results from suspected cases. The evaluation of the assay using samples from lineage III is needed for future studies.

In this study, an RT-LAMP assay for the detection of LASV isolates in southeastern and south-central Nigeria was developed by applying three specific subclade primer sets. The specificity of the assay is high even though the sensitivity appears to be less than that of the RT-PCR assay. However, the RT-LAMP assay is still efficient for viral detection in the LF endemic settings in Nigeria. It is also necessary to evaluate clinical samples from other states of the target region. These results provide a potentially rapid and specific diagnostic test for LASV lineage II strains in the acute phase of the disease and it may be used for field deployment during LASV outbreaks in southeastern and south-central Nigeria.

\section{Conflicts of interest}

The authors report no conflicts of interest.

\section{Funding}

This work was supported by a grant-in-aid from the Japan Agency for Medical Research and Development (AMED) (grant number JP18fk0108028) for JY. The funder had no role in study design, collection analysis and interpretation of data, decision to publish, or preparation of the manuscript.

\section{Acknowledgments}

The authors would like to thank Dr. Tansy Edwards, Department of Infectious Disease Epidemiology, London School of Hygiene \& Tropical Medicine, for her kind advice on the statistical evaluation of the RTLAMP assay results. 


\section{References}

Andersen, K.G., Shapiro, B.J., Matranga, C.B., Sealfon, R., Lin, A.E., Moses, L.M., Folarin, O.A., Goba, A., Odia, I., Ehiane, P.E., Momoh, M., England, E.M., Winnicki, S., Branco, L.M., Gire, S.K., Phelan, E., Tariyal, R., Tewhey, R., Omoniwa, O., Fullah, M., Fonnie, R., Fonnie, M., Kanneh, L., Jalloh, S., Gbakie, M., Saffa, S., Karbo, K., Gladden, A.D., Qu, J., Stremlau, M., Nekoui, M., Finucane, H.K., Tabrizi, S., Vitti, J.J., Birren, B., Fitzgerald, M., McCowan, C., Ireland, A., Berlin, A.M., Bochicchio, J., Tazon-Vega, B., Lennon, N.J., Ryan, E.M., Bjornson, Z., Milner, D.A., Lukens, A.K., Broodie, N., Rowland, M., Heinrich, M., Akdag, M., Schieffelin, J.S., Levy, D., Akpan, H., Bausch, D.G., Rubins, K., McCormick, J.B., Lander, E.S., Günther, S., Hensley, L., Okogbenin, S., Schaffner, S.F., Okokhere, P.O., Khan, S.H., Grant, D.S., Akpede, G.O., Asogun, D.A., Gnirke, A., Levin, J.Z., Happi, C.T., Garry, R.F., Sabeti, P.C., 2015. Clinical sequencing uncovers origins and evolution of Lassa virus. Cell 162, 738-750. https://doi.org/10.1016/j.cell.2015.07.020.

Bowen, M.D., Rollin, P.E., Ksiazek, T.G., Hustad, H.L., Bausch, D.G., Demby, A.H., Bajani, M.D., Peters, C.J., Nichol, S.T., 2000. Genetic diversity among Lassa virus strains. J. Virol. 74, 6992-7004. https://doi.org/10.1128/JVI.74.15.6992-7004.2000.

Branco, L.M., Boisen, M.L., Andersen, K.G., Grove, J.N., Moses, L.M., Muncy, I.J., Henderson, L.A., Schieffellin, J.S., Robinson, J.E., Bangura, J.J., Grant, D.S., Raabe, V.N., Fonnie, M., Sabeti, P.C., Garry, R.F., 2011. Lassa hemorrhagic fever in a late term pregnancy from northern sierra leone with a positive maternal outcome: case report. Virol. J. 8, 404. https://doi.org/10.1186/1743-422X-8-404.

Dahmane, A., van Griensven, J., Van Herp, M., Van den Bergh, R., Nzomukunda, Y., Prior, J., Alders, P., Jambai, A., Zachariah, R., 2014. Constraints in the diagnosis and treatment of Lassa Fever and the effect on mortality in hospitalized children and women with obstetric conditions in a rural district hospital in Sierra Leone. Trans. R. Soc. Trop. Med. Hyg. 108, 126-132. https://doi.org/10.1093/trstmh/tru009.

Demby, A.H., 1994. Early diagnosis of Lassa fever by reverse transcription-PCR. J. Clin. Microbiol. 32, 6.

Drosten, C., Gottig, S., Schilling, S., Asper, M., Panning, M., Schmitz, H., Gunther, S. 2002. Rapid detection and quantification of RNA of ebola and marburg viruses, Lassa virus, crimean-congo hemorrhagic fever virus, rift valley fever virus, dengue virus, and yellow fever virus by real-time reverse transcription-PCR. J. Clin. Microbiol. 40, 2323-2330. https://doi.org/10.1128/JCM.40.7.2323-2330.2002.

Drosten, C., Kümmerer, B.M., Schmitz, H., Günther, S., 2003. Molecular diagnostics of viral hemorrhagic fevers. Antiviral Res. 57, 61-87. https://doi.org/10.1016/S0166 3542(02)00201-2.

Ehichioya, D.U., Hass, M., Becker-Ziaja, B., Ehimuan, J., Asogun, D.A., Fichet-Calvet, E., Kleinsteuber, K., Lelke, M., ter Meulen, J., Akpede, G.O., Omilabu, S.A., Gunther, S., Olschlager, S., 2011. Current molecular epidemiology of Lassa virus in Nigeria. J. Clin. Microbiol. 49, 1157-1161. https://doi.org/10.1128/JCM.01891-10.

Fichet-Calvet, E., Rogers, D.J., 2009. Risk maps of Lassa fever in West Africa. PLoS Negl. Trop. Dis. 3, e388. https://doi.org/10.1371/journal.pntd.0000388.

Flatz, L., Bergthaler, A., de la Torre, J.C., Pinschewer, D.D., 2006. Recovery of an arenavirus entirely from RNA polymerase I/II-driven cDNA. Proc. Natl. Acad. Sci. 103, 4663-4668. https://doi.org/10.1073/pnas.0600652103.

Fukuma, A., Kurosaki, Y., Morikawa, Y., Grolla, A., Feldmann, H., Yasuda, J., 2011. Rapid detection of Lassa virus by reverse transcription-loop-mediated isothermal amplification. Microbiol. Immunol. 55, 44-50. https://doi.org/10.1111/j.1348-0421.2010. 00286.x.

Gabriel, M., Adomeh, D.I., Ehimuan, J., Oyakhilome, J., Omomoh, E.O., Ighodalo, Y., Olokor, T., Bonney, K., Pahlmann, M., Emmerich, P., Lelke, M., Brunotte, L., Ölschläger, S., Thomé-Bolduan, C., Becker-Ziaja, B., Busch, C., Odia, I., OgbainiEmovon, E., Okokhere, P.O., Okogbenin, S.A., Akpede, G.O., Schmitz, H., Asogun, D.A., Günther, S., 2018. Development and evaluation of antibody-capture immunoassays for detection of Lassa virus nucleoprotein-specific immunoglobulin $\mathrm{M}$ and G. PLoS Negl. Trop. Dis. 12, e0006361. https://doi.org/10.1371/journal.pntd. 0006361.

Goba, A., Khan, S.H., Fonnie, M., Fullah, M., Moigboi, A., Kovoma, A., Sinnah, V., Yoko, N., Rogers, H., Safai, S., Momoh, M., Koroma, V., Kamara, F.K., Konowu, E., Yillah, M., French, I., Mustapha, I., Kanneh, F., Foday, M., McCarthy, H., Kallon, T., Kallon, M., Naiebu, J., Sellu, J., Jalloh, A.A., Gbakie, M., Kanneh, L., Massaly, J.L.B., Kargbo, D., Kargbo, B., Vandi, M., Gbetuwa, M., Gevao, S.M., Sandi, J.D., Jalloh, S.C., Grant, D.S., Blyden, S.O., Crozier, I., Schieffelin, J.S., McLellan, S.L., Jacob, S.T., Boisen, M.L., Hartnett, J.N., Cross, R.W., Branco, L.M., Andersen, K.G., Yozwiak, N.L., Gire, S.K., Tariyal, R., Park, D.J., Haislip, A.M., Bishop, C.M., Melnik, L.I., Gallaher, W.R., Wimley, W.C., He, J., Shaffer, J.G., Sullivan, B.M., Grillo, S., Oman, S., Garry, C.E., Edwards, D.R., McCormick, S.J., Elliott, D.H., Rouelle, J.A., Kannadka, C.B., Reyna, A.A., Bradley, B.T., Yu, H., Yenni, R.E., Hastie, K.M., Geisbert, J.B., Kulakosky, P.C., Wilson, R.B., Oldstone, M.B.A., Pitts, K.R., Henderson, L.A., Robinson, J.E., Geisbert, T.W., Saphire, E.O., Happi, C.T., Asogun, D.A., Sabeti, P.C., Garry, R.F., 2016. An outbreak of ebola virus disease in the Lassa Fever Zone. J. Infect. Dis. 214 S110-S121. https://doi.org/10.1093/infdis/jiw239.

Hallam, H.J., Hallam, S., Rodriguez, S.E., Barrett, A.D.T., Beasley, D.W.C., Chua, A., Ksiazek, T.G., Milligan, G.N., Sathiyamoorthy, V., Reece, L.M., 2018. Baseline mapping of Lassa fever virology, epidemiology and vaccine research and development. Npj Vaccines 3. https://doi.org/10.1038/s41541-018-0049-5.

Hamblion, E.L., Raftery, P., Wendland, A., Dweh, E., Williams, G.S., George, R.N.C., Soro, L., Katawera, V., Clement, P., Gasasira, A.N., Musa, E., Nagbe, T.K., 2018. The challenges of detecting and responding to a Lassa fever outbreak in an Ebola-affected setting. Int. J. Infect. Dis. 66, 65-73. https://doi.org/10.1016/j.ijid.2017.11.007.

Iseki, H., Alhassan, A., Ohta, N., Thekisoe, O.M.M., Yokoyama, N., Inoue, N., Nambota, A., Yasuda, J., Igarashi, I., 2007. Development of a multiplex loop-mediated isothermal amplification (mLAMP) method for the simultaneous detection of bovine Babesia parasites. J. Microbiol. Methods 71, 281-287. https://doi.org/10.1016/j. mimet.2007.09.019.

Kurosaki, Y., Grolla, A., Fukuma, A., Feldmann, H., Yasuda, J., 2010. Development and evaluation of a simple assay for marburg virus detection using a reverse transcriptionloop-mediated isothermal amplification method. J. Clin. Microbiol. 48, 2330-2336. https://doi.org/10.1128/JCM.01224-09.

Kurosaki, Y., Magassouba, N., Oloniniyi, O.K., Cherif, M.S., Sakabe, S., Takada, A., Hirayama, K., Yasuda, J., 2016. Development and evaluation of reverse transcriptionloop-Mediated isothermal amplification (RT-LAMP) assay coupled with a portable device for rapid diagnosis of ebola virus disease in Guinea. PLoS Negl. Trop. Dis. 10, e0004472. https://doi.org/10.1371/journal.pntd.0004472.

Kurosaki, Y., Martins, D.B.G., Kimura, M., Catena, A.D.S., Borba, M.A.C.S.M., Mattos, S., da, S., Abe, H., Yoshikawa, R., de Lima Filho, J.L., Yasuda, J., 2017. Development and evaluation of a rapid molecular diagnostic test for Zika virus infection by reverse transcription loop-mediated isothermal amplification. Sci. Rep. 7, 13503. https://doi org/10.1038/s41598-017-13836-9.

Manning, J.T., Forrester, N., Paessler, S., 2015. Lassa virus isolates from Mali and the Ivory Coast represent an emerging fifth lineage. Front. Microbiol. 6, 1037. https:// doi.org/10.3389/fmicb.2015.01037.

Mori, Y., Notomi, T., 2009. Loop-mediated isothermal amplification (LAMP): a rapid, accurate, and cost-effective diagnostic method for infectious diseases. J. Infect. Chemother. 15, 62-69. https://doi.org/10.1007/s10156-009-0669-9.

Nagamine, K., Watanabe, K., Ohtsuka, K., Hase, T., Notomi, T., 2001. Loop-mediated isothermal amplification reaction using a nondenatured template. Clin. Chem. 47, 1742-1743.

Nagamine, K., Hase, T., Notomi, T., 2002. Accelerated reaction by loop-mediated isothermal amplification using loop primers. Mol. Cell. Probes 16, 223-229. https://doi org/10.1006/mcpr.2002.0415.

Nigeria Centre for Disease Control, 2018. An Update of Lassa Fever Outbreak in Nigeria. URL https://ncdc.gov.ng/diseases/sitreps/?cat $=5 \&$ name $=$ An\%20update\%20of \%20Lassa\%20fever\%20outbreak\%20in\%20Nigeria (Accessed 27 November 2018).

Notomi, T., 2000. Loop-mediated isothermal amplification of DNA. Nucleic Acids Res. 28, 63e-63. https://doi.org/10.1093/nar/28.12.e63.

Notomi, T., Mori, Y., Tomita, N., Kanda, H., 2015. Loop-mediated isothermal amplification (LAMP): principle, features, and future prospects. J. Microbiol. 53, 1-5. https:// doi.org/10.1007/s12275-015-4656-9.

Ogawa, H., Miyamoto, H., Ebihara, H., Ito, K., Morikawa, S., Feldmann, H., Takada, A., 2011. Detection of all known filovirus species by reverse transcription-polymerase chain reaction using a primer set specific for the viral nucleoprotein gene. J. Virol. Methods 171, 310-313. https://doi.org/10.1016/j.jviromet.2010.11.010.

Olayemi, A., Cadar, D., Magassouba, N., Obadare, A., Kourouma, F., Oyeyiola, A. Fasogbon, S., Igbokwe, J., Rieger, T., Bockholt, S., Jérôme, H., Schmidt-Chanasit, J., Garigliany, M., Lorenzen, S., Igbahenah, F., Fichet, J.-N., Ortsega, D., Omilabu, S., Günther, S., Fichet-Calvet, E., 2016. New hosts of the Lassa virus. Sci. Rep. 6, 25280. https://doi.org/10.1038/srep25280.

Oloniniyi, O.K., Kurosaki, Y., Miyamoto, H., Takada, A., Yasuda, J., 2017. Rapid detection of all known ebolavirus species by reverse transcription-loop-mediated isothermal amplification (RT-LAMP). J. Virol. Methods 246, 8-14. https://doi.org/10.1016/j. jviromet.2017.03.011.

Oloniniyi, O.K., Unigwe, U.S., Okada, S., Kimura, M., Koyano, S., Miyazaki, Y., Iroezindu, M.O., Ajayi, N.A., Chukwubike, C.M., Chika-Igwenyi, N.M., Ndu, A.C., Nwidi, D.U., Abe, H., Urata, S., Kurosaki, Y., Yasuda, J., 2018. Genetic characterization of Lassa virus strains isolated from 2012 to 2016 in southeastern Nigeria. PLoS Negl. Trop. Dis. 12, e0006971. https://doi.org/10.1371/journal.pntd.0006971.

Olschlager, S., Lelke, M., Emmerich, P., Panning, M., Drosten, C., Hass, M., Asogun, D., Ehichioya, D., Omilabu, S., Gunther, S., 2010. Improved detection of Lassa virus by reverse transcription-PCR targeting the 5' region of S RNA. J. Clin. Microbiol. 48, 2009-2013. https://doi.org/10.1128/JCM.02351-09.

Raabe, V., Koehler, J., 2017. Laboratory diagnosis of Lassa fever. J. Clin. Microbiol. 55, 1629-1637. https://doi.org/10.1128/JCM.00170-17.

Safronetz, D., Lopez, J.E., Sogoba, N., Traore', S.F., Raffel, S.J., Fischer, E.R., Ebihara, H., Branco, L., Garry, R.F., Schwan, T.G., Feldmann, H., 2010. Detection of Lassa virus, Mali. Emerg. Infect. Dis. 16, 1123-1126. https://doi.org/10.3201/eid1607.100146.

Whitmer, S.L.M., Strecker, T., Cadar, D., Dienes, H.-P., Faber, K., Patel, K., Brown, S.M., Davis, W.G., Klena, J.D., Rollin, P.E., Schmidt-Chanasit, J., Fichet-Calvet, E., Noack, B., Emmerich, P., Rieger, T., Wolff, S., Fehling, S.K., Eickmann, M., Mengel, J.P., Schultze, T., Hain, T., Ampofo, W., Bonney, K., Aryeequaye, J.N.D., Ribner, B., Varkey, J.B., Mehta, A.K., Lyon, G.M., Kann, G., De Leuw, P., Schuettfort, G., Stephan, C., Wieland, U., Fries, J.W.U., Kochanek, M., Kraft, C.S., Wolf, T., Nichol, S.T., Becker, S., Ströher, U., Günther, S., 2018. New lineage of Lassa virus, Togo, 2016. Emerg. Infect. Dis. 24, 599-602. https://doi.org/10.3201/eid2403.171905.

Wong, Y.-P., Othman, S., Lau, Y.-L., Radu, S., Chee, H.-Y., 2018. Loop-mediated isothermal amplification (LAMP): a versatile technique for detection of micro-organisms. J. Appl. Microbiol. 124, 626-643. https://doi.org/10.1111/jam.13647.

World Health Organization, 2018. Lassa Fever. World Health Organ (Accessed 27 November 2018). http://www.who.int/news-room/fact-sheets/detail/lassa-fever. 